\title{
DYING JUSTICE: A CASE FOR DECRIMINALIZING EUTHANASIA AND ASSISTED SUICIDE IN CANADA, JOCELYN DOWNIE (TORONTO: UNIVERSITY OF TORONTO PRESS, 2004)
}

In November 2004, a well-established and trusted Québec television station featured a choking documentary about Manon Brunelle, a young woman suffering from multiple sclerosis, who had made the decision to fly to Switzerland to benefit from the assistance in dying that the Zurich-based Dignitas Association legally provides to persons suffering from incurable diseases. The authors of the documentary - well known in the Québecois cultural milieu for their outspoken and vitriolic social critique of existing inequalities and injustices present a strong and warm portrait of Manon during the last few months of her life; a portrait that culminates with the authors travelling to Zurich with Manon Brunelle in order to catch on film her last minutes of life. Manon committed suicide in a lucid and peaceful manner with the assistance of the Dignitas staff.

Rather than being voyeuristic and sensationalistic, the documentary conveys a sophisticated and respectful approach to this young woman's long-lasting and morally debilitating suffering. Whether or not the authors anticipated the end result, it remains that the documentary is a powerful testament to the pitiful state in which the political milieu and criminal laws of Canada find themselves today. The film unveils a series of social, political and medical inadequacies within Canadian society such as the inertia of the political classes, the deficiencies of today's medicine vis-à-vis degenerative illnesses, and the general hypocrisy of Canadian society that promotes the sanctity of life upfront, but turns a blind eye on the enduring presence of wars worldwide, suicides, the judicial defence of self-defence, fatal overdoses from poor quality street drugs, medical practices related to end-of-life processes and. last but not least, the known existence in Canada of underground networks of medical professionals who provide unregulated assistance to those wishing to commit suicide before degenerative diseases rob them of their last shred of dignity (such as AIDS victims). In this unfortunate state of affairs, one ought not to leave criminal laws unturned, as their rigidity and hypocrisy are pivotal in promoting juridical ambiguity and political weakness within Canadian society. As an example of such two-facedness, euthanasia is defined formally as a "murder" under s. 229 of the Canadian Criminal Code, 'but is recurrently prosecuted either as involuntary manslaughter or under administration of a noxious substance provisions.

It is this formal rigidity and hypocrisy in the utilization of criminal laws within the judiciary that Jocelyn Downic attempts to raise and critique in her book entitled Dying. Justice. ${ }^{2}$ Divided into three parts comprising a total of twelve short to medium length chapters, this monograph endeavours to present a well-documented and convincingly argued legal regime for the decriminalization of euthanasia and assisted suicide in Canada. More precisely, Downie's underlying premise is that the laws concerning all forms of assisted death - such as assisted suicide, euthanasia, withholding or withdrawing of medical treatment - are all in dire need of clarification and reform. With that in mind, she embarks on a prudent, meticulous and thoughtful argumentation of an array of legal and moral issues deemed problematic within the socio-legal assemblage surrounding assisted death in Canada. The author's argumentative 
scheme is separated into two clear and interrelated components: what the law is and what the law should be.

In Part One of her argument, Downie presents a descriptive summary of the current legal regimes (that is, common-law, federal and provincial legislation) in relation to various forms of assisted death in Canada, be it the withholding or withdrawing of potentially life-sustaining treatment, potentially life-shortening palliative treatment, assisted suicide or euthanasia. The author concludes that these legal regimes are generally characterized by a historical progression toward the recognition in law of competent individuals' end-of-life wishes, although some legislative ambiguity remains, especially around the issue of mature minors and unilateral withholding or withdrawing of treatment (that is, despite a patient's expressed wishes to the contrary). Such ambiguity appears to also be looming in relation to the provision of potential life-shortening palliative treatment, especially the law's lack of a clear definition for notions of wanton and reckless disregard for life. In the matters of assisted suicide and euthanasia specifically, Downie's conclusions differ slightly at the outset of her analysis of these two legal regimes. She notes, on the one hand, that although assisted suicide is clearly criminalized as a "serious" crime incurring a maximum sentence of fourteen years of imprisonment, few cases are prosecuted, fewer are convicted and among those convictions, most sentences are not substantial. ${ }^{3}$ On the other hand, and as alluded to before, although the Criminal Code sends a strong message that euthanasia will not be tolerated by categorizing it as a murder, the Canadian courts have been starkly singing a different tune, essentially sentencing Canadians to probation terms ${ }^{4}$ (Robert Latimer being a notable exception with his life sentence without parole eligibility for ten years). ${ }^{5}$

It is in Part Two that Jocelyn Downie begins to unfold the central argument of her book, which is that assisted suicide and euthanasia should be regulated under the same legal regime as are the practices of withholding or withdrawing potentially life-sustaining treatment. The more interesting matter of this second part of the book resides in the author's presentation of the alternative legal regime she proposes for a more adequate legislative regulation of assisted death through the withholding or withdrawing of life-sustaining treatment. She argues that on the basis of legally determinant values such as life, dignity and autonomy (discussed in chapters five and six), the respect of individuals' refusal of life-sustaining treatment should not be delimited - as it typically is today - by age, terminal illness, unrelievable physical pain, the absence of reasonable alternatives or the type of treatment being refused. Via sound sociopolitical arguments, Downie presents, in chapter seven, convincing evidence against the current use of the above mentioned components of contemporary legal decision-making. This (rather brief) exposé may be the most clearly sociological contribution of the book.

Another attractive contribution is surely Downie's critique and invalidation of the current existing test for respecting an individual's refusal of life-sustaining treatment, and her proposal of a modified version of it. Although the mere disclosure of information is currently necessary to achieve informed consent under the existing test, Downic suggests that one's actual understanding of the information disclosed - rather than the actual act of disclosing the 
information - ought to be the foremost element underlying informed consent. ${ }^{\circ}$ Furthermore, Downie joins a long list of social observers who recommend that the modified test be spelled out in statute rather than in common law in order to bring the burden of law reform on legislatures rather than on individuals; to potentially clarify the situation with one piece of legislation rather than through a piecemeal approach within the court apparatus, and finally to allow governments to resolve moral and ethical issues and to provide the adequate social space for a wider debate than that possible through the courts.'

Downie's proposal of a modified test is further supported by the author's extensive, fortypage argumentation (in chapters eight through ten) of the invalidity of three discursive components traditionally invoked in socio-legal debates on assisted death: the juridical distinctions generally drawn (for example, act versus omission); the concerns commonly expressed (for example, suffering as a source of meaning and understanding); and the predictable "slippery slope" arguments. These pages comprise, in my opinion. the most appealing and persuasive portion of Downie's audacious contention in this book. It is here. precisely, that she gets to the crux of her argumentative intent, and where her scholarly contribution lies.

As the author competently demonstrates, the current socio-legal debate on assisted death is quintessentially moral. The problematization of assisted suicide takes place within the quicksand of more global social transformations such as the globalization of exchanges (including the exchange of ideas), the expansion of neo-liberalisin with its corollaries of economic pragmatism and financial austerity (of which hospitals are clear victims) and the appreciable reinforcement of individualism. It also, and primarily, takes place within the present social movement of contestation observable in Western societies. This generalized dissent is being translated into a movement in which social actors seek new meanings in multifarious spheres of the social world. This, in turn, fragments and tears apart the world of meanings. Actors increasingly dismiss some of the more major social and moral values that had presided over, until recently, the organization of social relations, to the point where the absence of common social references has become one of the more substantial social trends of present modern societies. To wit, if a debate is currently palpable on assisted death, it is precisely because assisted suicide is criminalized, and because there no longer exists a moral consensus around the appropriateness of the criminal law as the preferred means of social intervention in circumstances related to the self-determination of the human body. Hence, the ( $r$ iminul Code no longer is the object of consensus. A good part of the problematization of assisted suicide resides, then, in the presence of multiple moralities, some of which - more contemporary and often still marginal - are acquiring enough political capital to make themselves heard, often through the political arena, the public tribunes or the court apparatus. Jocelyn Downie's book is evidence of this multiplicity of moral horizons and. as such, is a very timely piece of work.

Joane Martel

Department of Suciology

University of Alberta 